\title{
THE ACUTE EFFECT OF ERYTHROPOIETIN ON GLUCOSE LEVELS DURING ISCHEMIA REPERFUSION INJURY IN RATS
}

\author{
Constantinos Tsompos ${ }^{1}$, Constantinos Panoulis ${ }^{2}$, Konstantinos Toutouzas ${ }^{3}$, George Zografos $^{4}$, \\ Apostolos Papalois ${ }^{5}$ \\ ${ }^{1}$ Consultant A, Department of Obstetrics \& Gynecology, Messolonghi County Hospital, Etoloakarnania, Greece, \\ ${ }^{2}$ Assistant Professor, Department of Obstetrics \& Gynecology, Aretaieion Hospital, Athens University, Attiki, Greece, \\ ${ }^{3}$ Assistant Professor, Department of Surgery, Ippokrateion General Hospital, Athens University, Attiki, Greece, \\ ${ }^{4}$ Professor, Department of Surgery, Ippokrateion General Hospital, Athens University, Attiki, Greece, \\ ${ }^{5}$ Director, Exprerimental Research Center ELPEN Pharmaceuticals, S.A. Inc., Co.
}

\begin{abstract}
ABSTRAK
Tujuan dari studi eksperimental ini adalah untuk menguji pengaruh erythropoietin pada model tikus dan khususnya dalam iskemia reperfusi (HR) protokol. Pengaruh molekul yang dipelajari biokimia menggunakan darah berarti glukosa (Gl) tingkat. Bahan dan metode: 40 tikus dari rata-rata berat 247,7 g yang digunakan dalam penelitian ini. tingkat gl diukur pada 60 menit (kelompok A dan C) dan pada 120 menit (kelompok B dan D) dari reperfusi. Erythropoietin diberikan hanya pada kelompok C dan D. Hasil itu bahwa pemberian Epo non-signifikan meningkatkan tingkat $\mathrm{gl}$ oleh 5,59\% $+6.46 \%(p=0,3208)$. Waktu reperfusi non-signifikan meningkatkan tingkat gl sebesar 5,63\% + 6.45\% $(p=0,4098)$. Namun, administrasi erythropoietin dan waktu reperfusi bersamasama menghasilkan efek gabungan non signifikan dalam meningkatkan tingkat gl sebesar 4,94\% + 3,81\% $(p=0,1892)$. Kesimpulan: Hasil penelitian ini menunjukkan bahwa pemberian erythropoietin, waktu reperfusi, atau interaksi mereka non-signifikan meningkatkan kadar glukosa darah dalam jangka pendek. Data bibliografi berlawanan dianggap lebih dapat diandalkan, sampai sampel yang lebih besar memberikan hasil yang lebih jelas. (FMI 2016;52:14-18)
\end{abstract}

Kata kunci: iskemia,eritropoietin, kedar gula, reperfusi

\begin{abstract}
The aim of this experimental study was to examine the effect of erythropoietin on rat model and particularly in an ischemia reperfusion (HR) protocol. The effect of that molecule was studied biochemically using blood mean glucose (Gl) levels. Materials and methods: 40 rats of mean weight $247.7 \mathrm{~g}$ were used in the study. Gl levels were measured at 60 min (groups A and C) and at 120 min (groups $B$ and D) of reperfusion. Erythropoietin was administered only in groups $C$ and $D$. Results were that Epo administration non-significantly increased the gl levels by $5.59 \%+6.46 \%(p=0.3208)$. Reperfusion time non-significantly increased the gl levels by $5.63 \%+6.45 \%(p=0.4098)$. However, erythropoietin administration and reperfusion time together produced a non significant combined effect in increasing the gl levels by $4.94 \%+3.81 \%(p=0.1892)$. Conclusions: Results of this study indicate that erythropoietin administration, reperfusion time, or their interaction non-significantly increase the blood glucose levels in short-term. Opposite bibliographic data are considered more reliable, until a greater sample provide clearer results. (FMI 2016;52:14-18)
\end{abstract}

Keywords: ischemia, erythropoietin, glucose levels, reperfusion

Correspondence: Tsompos Constantinos, Department of Obstetrics \& Gynecology, Mesologi County Hospital, Nafpaktou street. Mesologi 30200, Etoloakarnania, Greece. Tel: 00302631360237 \& 00306946674264 . Fax: 00302106811215. E-mail: Constantinostsompos@yahoo.com

\author{
Abbreviations: \\ Gl: glucose; Epo: erythropoietin; MBG: mean blood \\ glucose; AG: admission glucose
}

\section{INTRODUCTION}

Tissue ischemia reperfusion (IR) remain of the main causes of permanent or transient damage with serious implications on adjacent organs and certainly on patients' health. Although important progress has been made regarding the usage of erythropoietin (Epo) in managing this kind of damages, satisfactory answers have not been given yet to fundamental questions, as, by what velocity this factor acts, when should it be administered, and in which dosage. The particularly satisfactory action of Epo in stem blood cells recovery has been noted in several performed experiments. However, just few relative reports were found concerning Epo trial in IR experiments, not covering completely this particular matter. A meta-analysis of 13 published seric variables, coming from the same experimental setting, tried to provide a numeric evaluation of the Epo efficacy at the same endpoints (Table 1) (Tsompos et al 
2015a, Tsompos et al 2015b). Furthermore, several publications addressed trials of other similar molecules of growth factors to which the studied molecule also belongs to (Bader et al 2011, Wang et al 2011). The aim of this experimental study was to examine the effect of Epo on rat model and particularly in a pancreas IR protocol. The effect of that molecule was studied by measuring the blood mean glucose (Gl) levels.

\section{MATERIALS AND METHODS}

\section{Animal preparation}

This experimental study was lisenced by Veterinary Address of East Attiki Prefecture under 3693/12-112010 \& 14/10-1-2012 decisions. All settings needed for the study including consumables, equipment and substances used, were a courtesy of Exprerimental Research Center of ELPEN Pharmaceuticals Co. Inc. S.A. at Pikermi, Attiki. Accepted standards of humane animal care were adopted for Albino female Wistar rats. Normal housing in laboratory 7 days before the experiment included continuous access to water and food. The experiment was acute, that means that awakening and preservation of the rodents was not following the experiment. They were randomly delivered to four experimental groups by 10 animals in each one. Ischemia for $45 \mathrm{~min}$ followed by reperfusion for 60 min (group A). Ischemia for $45 \mathrm{~min}$ followed by reperfusion for $120 \mathrm{~min}$ (group B). Ischemia for $45 \mathrm{~min}$ followed by immediate Epo intravenous (IV) administration and reperfusion for $60 \mathrm{~min}$ (group C). Ischemia for $45 \mathrm{~min}$ followed by immediate Epo IV administration and reperfusion for $120 \mathrm{~min}$ (group D). The molecule Epo dosage was $10 \mathrm{mg} / \mathrm{Kg}$ body weight of animals.

At first, the animals were submitted into prenarcosis followed by general anesthesia. The detailed anesthesiologic technique is described in related references (Tsompos et al 2015a, Tsompos et al 2015b). Oxygen supply, electrocardiogram and acidometry were continuously provided during whole experiment performance.

The protocol of IR was followed. Ischemia was caused by forceps clamping inferior aorta over renal arteries for $45 \mathrm{~min}$ after laparotomic access had been achieved. Reperfusion was induced by removing the clamp and reestablishment of inferior aorta patency. The molecules were administered at the time of reperfusion, through inferior vena cava after catheterization had been achieved. The Gl levels measurements were performed at 60 min of reperfusion (for groups $\mathrm{A}$ and $\mathrm{C}$ ) and at 120 min of reperfusion (for groups B and D). The mean weight of the forty (40) female Wistar albino rats used was $247.7 \mathrm{~g}$ [Std. Dev: $34.99172 \mathrm{~g}$ ], with min weight $\geq$ $165 \mathrm{~g}$ and max weight $\leq 320 \mathrm{~g}$. Rats' weight could be potentially a confusing factor, e.g. the more obese rats to have greater gl levels. This suspicion was investigated.

Model of ischemia-reperfusion injury in each groups was as follows: Control groups: 20 control rats (mean mass $252.5 \mathrm{~g}$ [Std. Dev: $39.31988 \mathrm{~g}$ ] suffered by ischemia for $45 \mathrm{~min}$ followed by reperfusion. Group A: Reperfusion lasted for $60 \mathrm{~min}(\mathrm{n}=10$ controls rats) mean mass 243 g [Std. Dev: $45.77724 \mathrm{~g}$ ], mean gl levels $420.6 \mathrm{mg} / \mathrm{dl}$ [Std. Dev: $69.20373 \mathrm{mg} / \mathrm{dl}$ ] (Table 2). Group B: Reperfusion lasted for $120 \mathrm{~min}(\mathrm{n}=10$ controls rats) mean mass $262 \mathrm{~g}$ [Std. Dev: $31.10913 \mathrm{~g}$ ], mean gl levels $423.6 \mathrm{mg} / \mathrm{dl}$ [Std. Dev: $102.9997 \mathrm{mg} / \mathrm{dl}$ ] (Table 2). Erythropoietin group: 20 Epo rats (mean mass 242.9 $\mathrm{g}$ [Std. Dev: $30.3105 \mathrm{~g}$ ] suffered by ischemia for $45 \mathrm{~min}$ followed by reperfusion in the beginning of which 10 $\mathrm{mg}$ Epo $/ \mathrm{kg}$ body weight were IV administered. Group C: Reperfusion lasted for $60 \mathrm{~min}(\mathrm{n}=10$ Epo rats) mean mass $242.8 \mathrm{~g}$ [Std. Dev: $29.33636 \mathrm{~g}$ ], mean gl levels $423.8 \mathrm{mg} / \mathrm{dl}$ [Std. Dev: $73.60676 \mathrm{mg} / \mathrm{dl}$ ] (Table 2). Group D: Reperfusion lasted for $120 \mathrm{~min}(\mathrm{n}=10$ Epo rats) mean mass $243 \mathrm{~g}$ [Std. Dev: $32.84644 \mathrm{~g}$ ], mean gl levels $470.3 \mathrm{mg} / \mathrm{dl}$ [Std. Dev: $101.9979 \mathrm{mg} / \mathrm{dl}$ ] (Table 2).

\section{RESULTS}

Weight comparison of every one from 4 rats groups initially was performed with each other from 3 remained groups applying statistical paired t-test (Table 3). Any emerging significant difference among gl levels, was investigated whether owed in the above mentioned significant weight correlations. Gl levels comparison of every one from 4 rats groups initially was performed with each other from 3 remained groups applying statistical paired t-test (Table 3). Applying generalized linear models (glm) with dependant variable the $\mathrm{gl}$ levels and independent variables the Epo administration or no, the reperfusion time and their interaction, resulted in: Epo administration non-significantly increased the gl levels by $24.75 \mathrm{mg} / \mathrm{dl}[-31.36051 \mathrm{mg} / \mathrm{dl}$ - 80.86051 $\mathrm{mg} / \mathrm{dl}](\mathrm{P}=0.3775)$. This finding was in accordance with the results of paired t-test $(\mathrm{p}=0.2642)$. Reperfusion time non-significantly increased the gl levels by 24.95 $\mathrm{mg} / \mathrm{dl}[-31.15096 \mathrm{mg} / \mathrm{dl}-81.05096 \mathrm{mg} / \mathrm{dl}](\mathrm{P}=0.3736)$, also in accordance with paired t-test $(\mathrm{p}=0.4461)$. However, erythropoietin administration and reperfusion time together produced a non significant combined effect in increasing the gl levels by $22.06364 \mathrm{mg} / \mathrm{dl} \mathrm{[-}$ $11.34881 \mathrm{mg} / \mathrm{dl}$ - $55.47608 \mathrm{mg} / \mathrm{dl}] \quad(\mathrm{P}=0.1892)$. Reviewing the above and table 3 , the tables 4 and 5 sum 
up concerning the alteration influence of Epo in connection with reperfusion time. Inserting the rats weight as independent variable at glm, a non significant relation turns on gl levels ( $\mathrm{p}=0.2104)$, so as to further investigation is not needed.

Table 1. The erythropoietin (Epo) influence (+SD) on the levels of some seric1 variables concerning reperfusion (rep) time

\begin{tabular}{|c|c|c|c|c|c|c|c|c|}
\hline Variable & 1h rep & p-value & $1.5 \mathrm{~h}$ rep & $\mathrm{p}$-value & 2h rep & p-value & interaction of Epo and rep & p-value \\
\hline $\begin{array}{l}\text { white blood } \\
\text { cells }\end{array}$ & $+24.01 \% \pm 13.38 \%$ & 0.1012 & $+22.09 \%+9.11 \%$ & 0.0351 & $+20.17 \% \pm 12.94 \%$ & 0.0902 & $+14.63 \% \pm 5.40 \%$ & 0.0080 \\
\hline hematocrit $^{2}$ & $+0.14 \%+2.89 \%$ & 0.9626 & $-0.61 \%+2.37 \%$ & 0.8072 & $-1.37 \%+4.05 \%$ & 0.7485 & $+0.24 \%+1.38 \%$ & 0.8586 \\
\hline $\begin{array}{l}\text { mean } \\
\text { corpuscular } \\
\text { hemoglobin }\end{array}$ & $+0.01 \% \pm 1.29 \%$ & 0.9904 & $+0.67 \% \pm 0.80 \%$ & 0.3549 & $+1.34 \% \pm 1.08 \%$ & 0.1509 & $-0.36 \% \pm 0.47 \%$ & 0.4430 \\
\hline $\begin{array}{l}\text { platelet } \\
\text { distribution } \\
\text { width }\end{array}$ & $+1.60 \% \pm 0.80 \%$ & 0.0765 & $+1.36 \% \pm 0.58 \%$ & 0.0205 & $+1.13 \% \pm 0.74 \%$ & 0.1152 & $+0.37 \%+0.37 \%$ & 0.0615 \\
\hline plateletcrit & $-16.47 \%+10.40 \%$ & 0.0921 & $-13.74 \% \pm 7.01 \%$ & 0.0158 & $-11.01 \% \pm 7.34 \%$ & 0.0882 & $-6.88 \%+3.69 \%$ & 0.0615 \\
\hline uric acid & $+10.13 \%+15.10 \%$ & 0.4917 & $+15.86 \%+10.21 \%$ & 0.1408 & $+21.59 \%+15.45 \%$ & 0.1940 & $+9.33 \%+6.16 \%$ & 0.1264 \\
\hline total protein & $-0.02 \% \pm 2.47 \%$ & 0.9904 & $-1.27 \%+1.51 \%$ & 0.3721 & $-2.52 \%+2.03 \%$ & 0.1509 & $-0.68 \%+2.48 \%$ & 0.4430 \\
\hline $\begin{array}{l}\text { alkaline } \\
\text { phosphatase }\end{array}$ & $+0.20 \% \pm 18.57 \%$ & 0.9904 & $+10.70 \% \pm 12.78 \%$ & 0.3549 & $+21.20 \%+17.11 \%$ & 0.1509 & $+5.79 \% \pm 7.72 \%$ & 0.4430 \\
\hline $\begin{array}{l}\text { acid } \\
\text { phosphatase }\end{array}$ & $+0.06 \%+5.79 \%$ & 0.9904 & $+3.11 \%+3.71 \%$ & 0.3172 & $+6.16 \%+4.97 \%$ & 0.1509 & $+1.68 \% \pm 2.23 \%$ & 0.4430 \\
\hline CPK & $+0.15 \%+14.09 \%$ & 0.9904 & $+7.91 \%+9.44 \%$ & 0.3549 & $+15.67 \%+12.65 \%$ & 0.1509 & $+4.28 \%+5.70 \%$ & 0.4430 \\
\hline LDH & $+0.08 \% \pm 7.92 \%$ & 0.9904 & $+4.48 \%+5.35 \%$ & 0.3549 & $+8.89 \%+7.17 \%$ & 0.1509 & $+2.42 \%+3.22 \%$ & 0.4430 \\
\hline sodium & $+0.72 \% \pm 0.74 \%$ & 0.3054 & $+0.21 \% \pm 0.63 \%$ & 0.7136 & $-0.29 \%+1.09 \%$ & 0.7670 & $-0.11 \%+0.38 \%$ & 0.7531 \\
\hline progesterone & $-0.20 \%+18.65 \%$ & 0.9904 & $-8.86 \%+10.58 \%$ & 0.3549 & $-17.53 \%+14.15 \%$ & 0.1509 & $-4.79 \%+6.39 \%$ & 0.4430 \\
\hline mean & $+1.57 \%+8.76 \%$ & 0.6894 & $+3.22 \%+9.49 \%$ & 0.3228 & $+4.87 \%+12.29 \%$ & 0.2353 & $+1.99 \%+5.63 \%$ & 0.3823 \\
\hline
\end{tabular}

Table 2. Weight and mean glucose levels and Std. Dev. of groups

\begin{tabular}{clll}
\hline Groups & Variable & \multicolumn{1}{c}{ Mean } & \multicolumn{1}{c}{ Std. Dev } \\
\hline A & Weight & $243 \mathrm{~g}$ & $45.77724 \mathrm{~g}$ \\
& Glucose & $420.6 \mathrm{mg} / \mathrm{dl}$ & $69.20373 \mathrm{mg} / \mathrm{dl}$ \\
$\mathrm{B}$ & Weight & $262 \mathrm{~g}$ & $31.10913 \mathrm{~g}$ \\
& Glucose & $423.6 \mathrm{mg} / \mathrm{dl}$ & $102.9997 \mathrm{mg} / \mathrm{dl}$ \\
$\mathrm{C}$ & Weight & $242.8 \mathrm{~g}$ & $29.33636 \mathrm{~g}$ \\
& Glucose & $423.8 \mathrm{mg} / \mathrm{dl}$ & $73.60676 \mathrm{mg} / \mathrm{dl}$ \\
$\mathrm{D}$ & Weight & $243 \mathrm{~g}$ & $32.84644 \mathrm{~g}$ \\
& Glucose & $470.3 \mathrm{mg} / \mathrm{dl}$ & $101.9979 \mathrm{mg} / \mathrm{dl}$ \\
\hline
\end{tabular}

Table 3. Statistical significance of mean values difference for groups (DG) after statistical paired t test application.

\begin{tabular}{lccc}
\hline DG & Variable & Difference & p-value \\
\hline A-B & Weight & $-19 \mathrm{~g}$ & 0.2423 \\
& Glucose & $-3 \mathrm{mg} / \mathrm{dl}$ & 0.9165 \\
A-C & Weight & $0.2 \mathrm{~g}$ & 0.9900 \\
& Glucose & $-3.2 \mathrm{mg} / \mathrm{dl}$ & 0.9401 \\
A-D & Weight & $0 \mathrm{~g}$ & 1.0000 \\
& Glucose & $-49.7 \mathrm{mg} / \mathrm{dl}$ & 0.3125 \\
B-C & Weight & $19.2 \mathrm{~g}$ & 0.2598 \\
& Glucose & $-0.2 \mathrm{mg} / \mathrm{dl}$ & 0.9966 \\
B-D & Weight & $19 \mathrm{~g}$ & 0.1011 \\
& Glucose & $-46.7 \mathrm{mg} / \mathrm{dl}$ & 0.3765 \\
C-D & Weight & $-0.2 \mathrm{~g}$ & 0.9883 \\
& Glucose & $-46.5 \mathrm{mg} / \mathrm{dl}$ & 0.1897 \\
\hline
\end{tabular}


Table 4. The increasing influence of erythropoietin in connection with reperfusion time.

\begin{tabular}{lcccc}
\hline \multirow{2}{*}{ Increase } & \multicolumn{2}{c}{$95 \%$ c. in. } & \multirow{2}{*}{ Reperfusion time } & \multicolumn{2}{c}{$\mathrm{p}$ values } \\
\cline { 4 - 5 } & & & t-test & glm \\
\hline $3.2 \mathrm{mg} / \mathrm{dl}$ & $-63.92145 \mathrm{mg} / \mathrm{dl}-70.32145 \mathrm{mg} / \mathrm{dl}$ & $1.5 \mathrm{~h}$ & 0.9401 & 0.9213 \\
$24.75 \mathrm{mg} / \mathrm{dl}$ & $-31.36051 \mathrm{mg} / \mathrm{dl}-80.86051 \mathrm{mg} / \mathrm{dl}$ & 2642 & 0.3775 \\
$46.7 \mathrm{mg} / \mathrm{dl}$ & $-49.60499 \mathrm{mg} / \mathrm{dl}-143.005 \mathrm{mg} / \mathrm{dl}$ & $2 \mathrm{~h}$ & 0.3765 & 0.3218 \\
$24.95 \mathrm{mg} / \mathrm{dl}$ & $-31.15096 \mathrm{mg} / \mathrm{dl}-81.05096 \mathrm{mg} / \mathrm{dl}$ & reperfusion time & 0.4461 & 0.3736 \\
$22.06364 \mathrm{mg} / \mathrm{dl}$ & $-11.34881 \mathrm{mg} / \mathrm{dl}-55.47608 \mathrm{mg} / \mathrm{dl}$ & Interaction & & 0.1892 \\
\hline
\end{tabular}

Table 5. The (\%) increasing influence of erythropoietin in connection with reperfusion time

\begin{tabular}{cccc}
\hline Increase & $+\mathrm{SD}$ & Reperfusion time & $\mathrm{p}$-values \\
\hline $0.75 \%$ & $+8.11 \%$ & $1 \mathrm{~h}$ & 0.9307 \\
$5.59 \%$ & $+6.46 \%$ & $1.5 \mathrm{~h}$ & 0.3208 \\
$10.44 \%$ & $+10.99 \%$ & $2 \mathrm{~h}$ & 0.3491 \\
$5.63 \%$ & $+6.45 \%$ & reperfusion time & 0.4098 \\
$4.94 \%$ & $+3.81 \%$ & Interaction & 0.1892 \\
\hline
\end{tabular}

\section{DISCUSSION}

The following clinical situations show how hyperglycemia favors ischemia. Gąsecki et al (2012) significantly associated favorable early outcome with adjustment for blood Gl level on admission in stroke patients $(P=0.001)$. Nardi et al $(2012)$ found that admission hyperglycemia ( $\geq 143 \mathrm{mg} / \mathrm{dL}$ ) is a strong and independent predictor for 72-hour fatality, especially in patients with no prior history of diabetes mellitus (overall: $\mathrm{OR}=4.0, \mathrm{p}=0.003$; non-diabetics: $\mathrm{OR}=4.9$, $\mathrm{p}=0.004)$. Admission hyperglycemia increases the risk of death in first-ever acute ischemic stroke patients (Nardi et al 2012). Yang et al (2010) found that elevated mean blood Gl (equal or greater than $7.1-8.5 \mathrm{mmol} / \mathrm{L}$ ) levels is an independent predictor and superior to admission Gl $(\mathrm{AG})(\mathrm{P}<0.001)$ on predicting 7 -and 30 day mortality and combined end point events on predicting short-term prognosis in acute myocardial infarction patients.

Also, the following situations reflect the effect Epo has on Gl levels. Lagarto et al (2012) observed a slight increase in Gl level within the normal range after 28 days of intra-nasal dosing of $6900 \mathrm{UI} / \mathrm{kg} /$ day Epo in healthy Wistar rats. Lee et al (2006) found that Gl and insulin concentrations were significantly lowered by the 25-day mountaineering activity where Epo increases, in male subjects group. Spaia et al (2000) proved the beneficial effect of Epo treatment on insulin resistance in non-obese, non-diabetic, stable dialysis patients, could be attributed to the Epo itself. Berridge \& Tan (1995) showed that growth factors can still promote short term cell survival responses, increasing affinity for $\mathrm{Gl}$ and thus the intracellular Gl concent-ration. Kokot et al (1994) noticed an increase of fasting insulinemia and a decrease of basal plasma level of glucagon and PP after 6 months of rHuEpo treatment. At that time point rHuEpo therapy also increased the response of insulin, glucagon, and gastrin to the test meal (Kokot et al 1994). Salvesen et al (1993) found the mean umbilical venous blood Epo significantly higher in diabetic pregnancies than the appropriate normal mean for gestation. There were significant associations between fetal hemoglobin and maternal glycosylated hemoglobin. Obviously, maternal hyperglycemia causes fetal hyperglycemia. The increase in fetal hemoglobin may be mediated by either Epo or hyperinsulinemia (Salvesen et al 1993). Mulay \& Congote (1985) found that Epo had a specific stimulatory effect on embryonictype globins in fetal liver cells in rat fetuses of diabetic mothers, which was significantly higher than control ones until 14 days of gestation. After this endpoint, these differences are abolished, but until then, a complicity between hyper-glycemia and Epo is denoted (Mulay \& Congote 1985). Katz et al (2010) demonstrated Epo-mediated decrease in blood Gl levels, attenuation of body weight gain and reduction of hemoglobin A1c in all mice models tested. Nakao et al (1998) correlated inversely the changes in HbAlc with both the changes in Hct and the reticulocyte counts by Epo treatment, though there were no significant changes in blood Gl levels during the 2-weeks study period in 15 non-diabetic hemodialysis patients.

\section{CONCLUSION}

Epo administration, reperfusion time, or their interaction non-significantly increase the blood glucose levels in short-term. The opposite bibliographic data are considered more reliable. A greater sample would provide 
more clearer results. Seven from nine studies show clearly that Epo has a definite declining effect on Gl levels.

\section{ACKNOWLEDGMENT}

This study was funded by Scholarship by the Experimental Research Center ELPEN Pharmaceuticals (E.R.C.E), Athens, Greece. The research facilities for this project were provided by the aforementioned institution.

\section{REFERENCES}

Bader A, Pavlica S, Deiwick A, Lotkova H, Kucera O, Darsow K, Bartel S, Schulze M, Lange HA, Cervinkova Z (2011). Proteomic analysis to display the effect of low doses of erythropoietin on rat liver regeneration. Life Sci 89, 827-833

Berridge MV and Tan AS (1995). Interleukin-3 facilitates glucose transport in a myeloid cell line by regulating the affinity of the glucose transporter for glucose: involvement of protein phosphorylation in transporter activation. Biochem J 305, 843-851

Gąsecki D, Rojek A, Kwarciany M, Boutouyrie P, Nyka W, Laurent S, Narkiewicz K (2012). Pulse wave velocity is associated with early clinical outcome after ischemic stroke. Atherosclerosis 225, 348-352

Katz O, Stuible M, Golishevski N, Lifshitz L, Tremblay ML, Gassmann M, Mittelman M, Neumann D (2010). Erythropoietin treatment leads to reduced blood glucose levels and body mass: insights from murine models. J Endocrinol 205, 87-95

Kokot F, Nieszporek T, Wiecek A, Marcinkowski W, Rudka R, Trembecki J (1994). Influence of long-term erythropoietin treatment on insulin, glucagon, pancreatic polypeptide, and gastrin secretion in haemodialysed patients. Nephrol Dial Transplant 9 Suppl 3, 35-39

Lagarto A, Bueno V, Sanchez JA, Couret M, Valdes O, Barzaga P, Lopez R, Guerra I, Gabilondo T, Vega Y, Beausoleil I (2012). Short-term intra-nasal erythropoietin administration with low sialic acid content is without toxicity or erythropoietic effects. Curr Neurovasc Res 9, 233-238

Lee WC, Chen SM, Wu MC, Hou CW, Lai YC, Laio YH, Lin CH, Kuo CH (2006). The role of dehydro- epiandrosterone levels on physiologic acclimatization to chronic mountaineering activity. High Alt Med Biol 7, 228-236

Mulay S and Congote LF (1985). Influence of maternal diabetes in rats on hemoglobin synthesis and uridine uptake by fetal liver cells. Diabetes 34, 212-216

Nakao T, Matsumoto H, Okada T, Han M, Hidaka H, Yoshino M, Shino T, Yamada C, Nagaoka Y (1998). Influence of erythropoietin treatment on hemoglobin A1c levels in patients with chronic renal failure on hemodialysis. Intern Med 37, 826-830

Nardi K, Milia P, Eusebi P, Paciaroni M, Caso V, Agnelli G (2012). Predictive value of admission blood glucose level on short-term mortality in acute cerebral ischemia. J Diabetes Complications 26, 70-76

Salvesen DR, Brudenell JM, Snijders RJ, Ireland RM, Nicolaides KH (1993). Fetal plasma erythropoietin in pregnancies complicated by maternal diabetes mellitus. Am J Obstet Gynecol 168, 88-94

Spaia S, Pangalos M, Askepidis N, Pazarloglou M, Mavropoulou E, Theodoridis S, Dimitrakopoulos K, Milionis A, Vayonas G (2000). Effect of short-term rHuEPO treatment on insulin resistance in haemodialysis patients. Nephron 84, 320-325

Tsompos C, Panoulis C, Toutouzas K (2015b). Efecto agudo de la eritropoyetina en los niveles del hematocrito durante una lesión por hipoxiareoxigenación en ratas. Prensa Médica Argentina [La] 101, 25-36

Tsompos C, Panoulis C, Toutouzas K, Zografos G, Papalois A (2015a). The effect of erythropoietin on total protein levels during ischemia reperfusion injury in rats. Int J Neurorehabilitation 2, 146

Wang Q, Gorbey S, Pfister F, Höger S, Dorn-Beineke A, Krügel K, Berrone E, Wu L, Korff T, Lin J, Busch S, Reichenbach A, Feng Y, Hammes HP (2011). Long-term treatment with suberythropoietic Epo is vaso- and neuroprotective in experimental diabetic retinopathy. Cell Physiol Biochem 27, 769-782

Yang YM, Liu Y, Zhu J, Tan HQ, Liang Y, Liu LS, Li JD, Zhang Y; China Clinical Trial of Reviparin and Metabolic Modulation in Acute Myocardial Infarction Treatment Evaluation (CREATE) Investigation Group (2010). Impact of first 24 hours mean blood glucose level on the prognosis of hospitalized patients with ST-segment elevation myocardial infarction. Zhonghua Xin Xue Guan Bing Za Zhi 38, 1065-1072 